\title{
МОДЕЛЮВАННЯ МЕХАНІЧНОГО НАВАНТАЖЕННЯ НА ЕНДОПРОТЕЗ НИЖНЬОЇ ЩЕЛЕПИ
}

\author{
Стасюк Ю.П. аспірант ФБМІ \\ stasuyk.yuriy@gmail.com \\ Черногорський Д. М.аспірант
} кафедри стоматології Інституту післядипломної освіти

НМУ імені ОО Богомольця cher103@meta.ua

Резнікова М.Ю., студент reznikovamaryna@gmail.com

Факультет біомедичної інженерії Національний технічний університет «Київський політехнічний інститут імені Ігоря Сікорського»

м. Київ, Україна

\begin{abstract}
Реферат - Проблема оптимізаиії способів ендопротезування дефектів нижньої щелепи на сьогодні залишається на піку актуальності. Вивчення біомеханіки імплантів дає змогу визначити внутрішні напруження $і$ деформації, дозволяє зрозуміти механізм порушень, а також обрати оптимальні методи лікування, визначити функиіональний прогноз хірургічних втручань.

В статті наведено результати натурного експерименту, під час якого проводилося випробування на згин в сагітальній площині титанового ендопротезу нижньої щелепи. Отримано діаграму деформування зразка та розраховано його жорсткість. Для визначення місиь локалізаиії максимальних напружень в ендопротезі, виконано математичне моделювання деформації зразка, в умовах, які повторюють проведений експеримент. Отримано результати розрахунку, які відображають місия з максимальним напруженням, щчо виникає в ендопротезі внаслідок дії на нього навантаження.
\end{abstract}

Ключові слова - біомеханіка, ендопротез, деформація, нижня щелепа, метод скінченних елементів, механічні навантаження, натурний експеримент, математичне моделювання, COMSOL Multiphysics 5.4

\section{I. ВСТУП}

За даними Центру медичної статистики MO3 України, у 2013 - 2015 рр. в Україні виконано понад 1009212 оперативних втручань на щелепно-лицевій ділянці та ротовій порожнині, з них 139764 - з приводу злоякісних новоутворень, що становить 13,9\% загальної кількості операцій та 4,5\% всіх хірургічних втручань [1], що свідчить про актуальність вивчення біомеханічних властивостей ендопротезів та інших штучних конструкцій, що використовуються в щелепно-лицевій хірургії.

На сьогодні створення індивідуальних скінченно елементних моделей (СЕМ) кісток обличчя $\epsilon$ перспективним напрямом біомеханічних досліджень. Автори вважають, що CEM у найближчому майбутньому можуть стати важливим компонентом планування щелепно-лицевих операцій i точного прогнозування складних біомеханічних реакцій при встановленні імплантатів, проведенні остеотомій та остеосинтезу кісток обличчя [2]

Сутність методу імітаційного моделювання має розрахунково-теоретичний характер із використанням математичних i предметних експериментальних моделей. У стоматологіï через складність об'єктів дослідження цей напрямок почав розвиватися порівняно нещодавно, разом із досягненням певної межі потужності електроннообчислювальної техніки [3].

Хірург може не тільки отримати цілісне уявлення про характер структурних порушень на ділянках зі складною архітектонікою, а й 3 високою точністю прогнозувати анатомічні та косметичні 
результати операцій на кістках лицевого черепа. Однак, при проведенні остеосинтезу і реконструктивно-відновних втручань важливо не тільки відновити форму кісткових структур, але i забезпечити їх здатність сприймати і перерозподіляти функціональні напруження в тому числі ті, що виникають при пережовуванні їжі [4].

\section{II. МЕТА ДОСЛІДЖЕННЯ}

Мета роботи: дослідження деформації імплантів нижньої щелепи, шляхом математичного моделювання навантажень, що виникають при здійсненні жувальних pyxiв.

\section{III. МАТЕРІАЛИ І МЕТОДИ}

Для досягнення поставленої мети було використано модель індивідуального титанового ендопротеза нижньої щелепи. Аналіз розподілу напружень і деформацій здійснювався за допомогою методу скінченних елементів i використання програмного комплексу COMSOL Multiphisics 5.4. Ретопологію геометрії було проведено в програмному середовищі Autodesk 3d's Max.

Для проведення біомеханічних випробувань було використано універсальну випробувальну машину TIRAtest-2151, за допомогою якої визначаються характеристики міцності та деформативності матеріалів i об'єктів при розтязі, стиску та згині. Швидкість деформування приймали рівною 0,5 мм/хв, що дає змогу отримати діаграми деформування, які майже не відрізняються від діаграм при статичному навантаженні [5].

\section{IV. РЕЗУЛЬТАТИ ТА ОБГОВОРЕННЯ}

Нижня щелепа при відкушуванні їжі працює за принципом важеля швидкості (важіль III роду), для якого притаманний програш у силі та виграш у швидкості змикання зубів. Остання може сягати 140 мм/с. Загалом нижня щелепа здійснює до 3000 жувальних рухів на добу. Зусилля, які при цьому розвиваються, є досить значними, сила прикусу здорової людини 3 інтактними зубними рядами i пародонтом може коливатися від 100 до 1500 Н і вище [6]. Її величина залежить від особливостей анатомічної будови нижньої щелепи i жувальних м'язів, співвідношення швидких та повільних волокон у м'язах, ступеня їх втоми, стану зубів і пародонта, наявності протетичних конструкцій та їх біомеханічних характеристик, структурно-функціонального стану кісткової тканини щелеп, особливостей конституції та характеристик жувального стереотипу людини, iii віку, статі, психоемоційного стану [7].

Для вивчення особливостей реакції ендопротезу на механічні навантаження та механізми його адаптації у функціональних умовах, що змінюються, та побудови достовірної математичної моделі було вирішено провести натурний експеримент, який зможе показати реальну поведінку матеріалу під час навантаження. Для визначення механічних властивостей зразка проводили його компресійне навантаження в універсальній випробувальній машині TIRATESR - 2151 (рис.1) [8]. Основними задачами проведення натурних експериментів було визначення загальних закономірностей поведінки протезу, виготовленого з титану в простих умовах деформування, отримання параметрів необхідних для побудови математичних моделей та перевірка їx точності і адекватності.

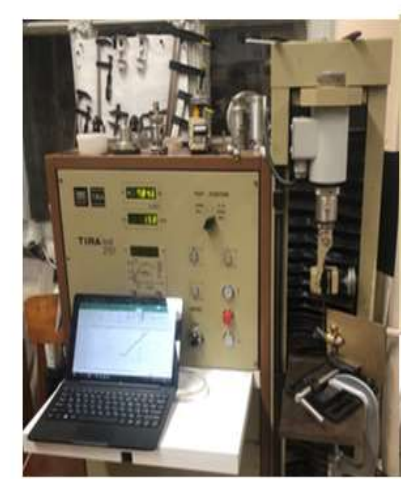

a

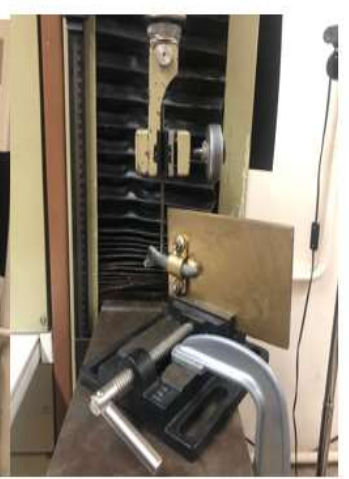

6
Pис.1. Процес проведення експерименту: а) вигляд випробувальної машини б) закріплення зразка

Було відтворено експериментальні моделі навантаження на протез нижньої щелепи: згин в сагітальній (YZ) площині, що $\epsilon$ домінуючою деформацією цієї зони в умовах відкушування та пережовування їжі. Навантаження прикладали у місцях прикріплення жувальних м’язів, вимірювали деформацію шляхом вертикального переміщення рухомого стола випробувальної машини за допомогою жорсткого сталевого стрижня, з’єднаного 3 динамометром дослідної машини. При відтворенні 
деформації згину при вертикальному навантаженні записували діаграму деформування (рис. 2).

Червоною точкою на графіку позначена границя пропорційності. 3 результатів дослідження помітно, що зразок починає деформуватися при навантаженні 880 Н. Межа пропорційності знаходиться на рівні 881 Н. Загалом сила, яка була прикладена, становила $900 \mathrm{H}$.

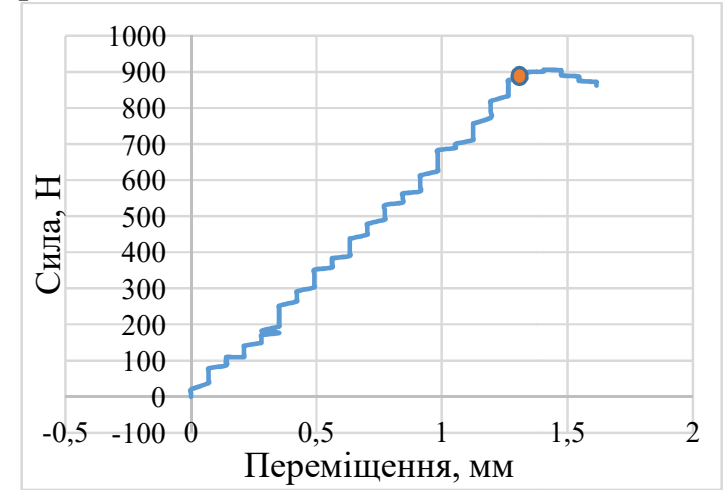

Puc.2. Діаграма деформування зразка на згин

Для визначення розподілу навантаження на поверхні імпланту, було виконане математичне моделювання. В геометрії ендопротезу, що була отримана на основі обробки зображень комп'ютерної томографії, наявна висока щільність полігональної сітки. Така щільність ускладнює процес розрахунку математичної моделі та $\epsilon$ нераціональним використанням ресурсів, тому було проведено ретопологію геометрії. Результати ретопології представлені на рисунку 3.

Для побудови низько полігональної геометрії використано програмний продукт Autodesk 3d's Max 2018.

Наступним кроком в COMSOL Multiphysics 5.4 було імпортовано отриману модель. У програмному середовищі відтворено елементи випробувальної конструкції та фіксації ендопротезу за допомогою функції «Geometry» (рис. 4). Так, елемент 1 відтворює елемент випробувальної машини, та несе функцію навантаження ендопротезу, геометрія якого позначена номером 3. Навантажувальний стержень відтворено комбінацією 2-ох примітивів «Cylinder» та «Sphere». Елемент під номером 2 виконаний за допомогою примітиву «Вох» відтворює пластину для закріплення зразка під час проведення експерименту.

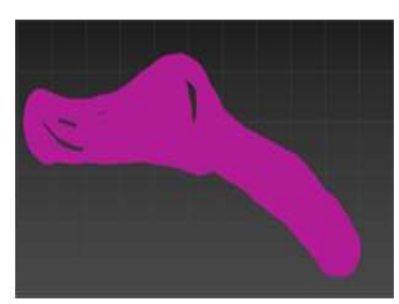

a)

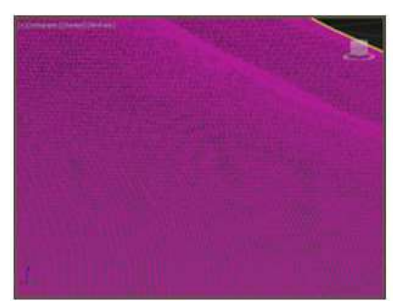

в)

Puc. 3. а) вигляд геометрії імпланту до проведення ретопології; б) вигляд геометрії імпланту після проведення ретопології; в) збільшене зображення сітки моделі ендопротезу до проведення ретопології; г) збільшене зображення сітки моделі ендопротезу після проведення ретопології

В ході проведення моделювання елемент 2 обирався жорстко закріпленим. До елементу номер 1 була прикладена сила, яка імітувала рух траверси випробувальної машини і навантаження, яке при цьому діяло на ендопротез. Так діапазон прикладеної сили становить від 0 до $900 \mathrm{H}$.

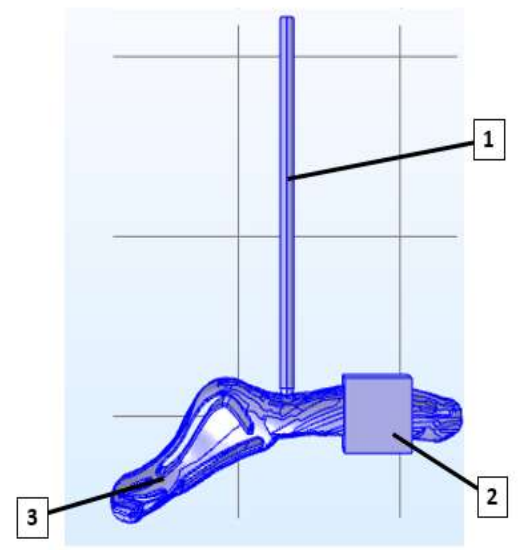

Puc. 4. Відтворення натурного експерименту в COMSOL Multiphysics 5.4: 1 - імітація сталевого стержня; 2 - закріплення зразка на підставці; 3 титановий ендопротез

На отриманій геометрії виконувався розрахунок математичної моделі розподілу напружень в ендопротезі. Всі елементи вважали гомогенними, фізико-механічні властивості задавалися відповідно до матеріалу ендопротезу (сплав титану ВТ6) та стержня (сталь AISI 304). 
Результати розрахунку моделі представлені на рис. 5 та рис. 6. Розрахунки виконані за допомогою модулю «Solid mechanics», де 3 використанням «Boundary load» описане зусилля, що діє на елемент 1. Різним кольором відповідно до шкали відображено розподіл навантаження в ендопротезі, значення наведено в $\mathrm{H} / \mathrm{m}^{2}$. На рис. 5 (б) наближено продемонстровано ділянки, які зазнають найбільшого тиску.

На рис. 6 результати обрахунку представлені на двовимірному графіку в перерізі площиною, яка проходить через центр сталевого стержня.

За результатами математичного моделювання можна зробити висновки, що максимальні напруження в імпланті виникають в місці прикладання сили - точка дотику стержня випробувальної машини та поверхні протезу, а також в місці жорсткого закріплення

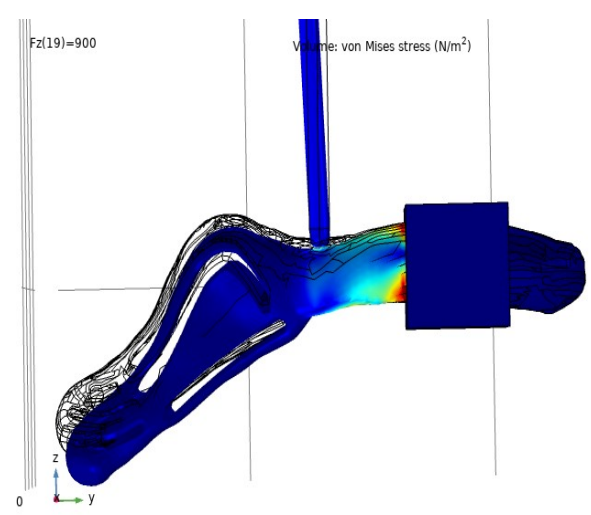

○

a)

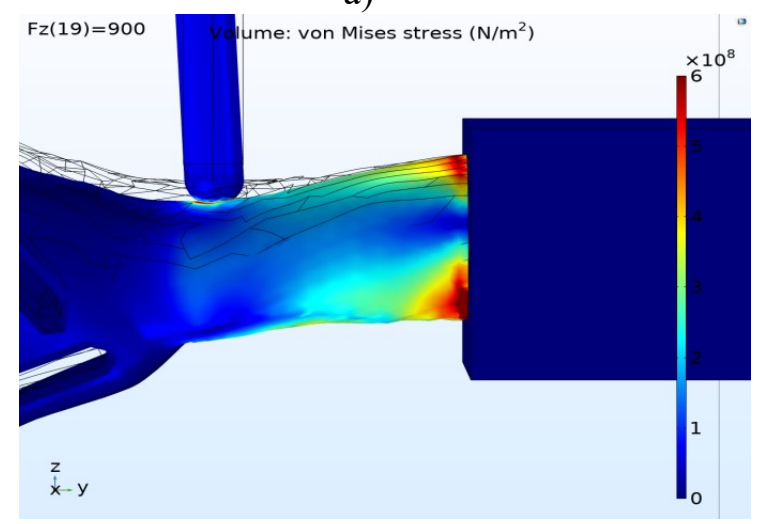

б)

Puc. 5. Розподіл напружень в титановому ендопротезі при моделюванні надання навантаження а) вигляд спереду; б) наближений вигляд

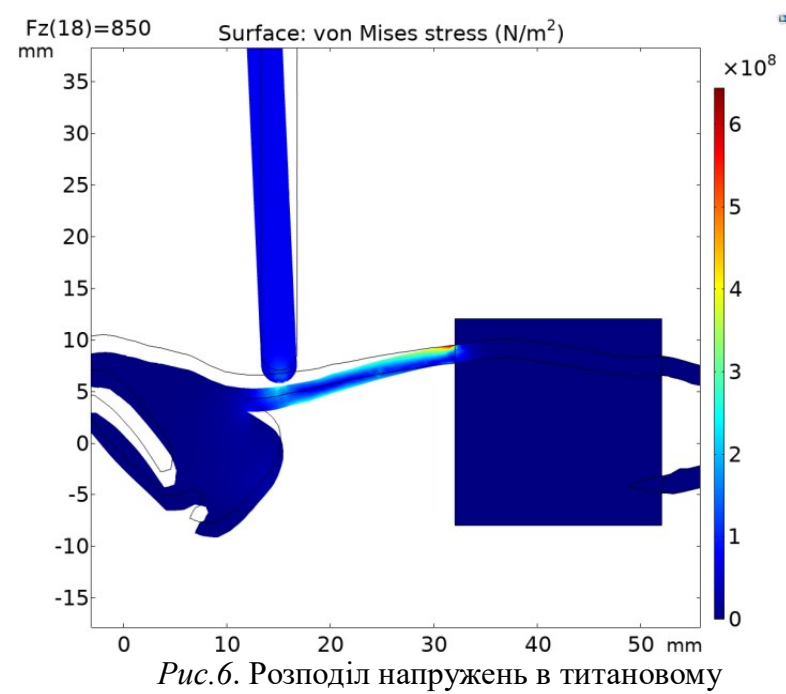

ендопротезі в розрізі, який отримано вертикальною площиною, що проходить через центр сталевого стрижня

Так максимальне значення в місці дотику становить 0,66 ГПа, а в місці кріплення 0,94 ГПа. Якщо ж оцінювати розподіл навантаження загалом, то деформації в інших частинах протезу майже не спостерігаються.

\section{V. ВИСНОВКИ}

1. Використання сучасних методів дослідження, зокрема методу скінченних елементів для виконання біомеханічних досліджень, є перспективним напрямом.

2. Проведено натурний експеримент, під час якого було здійснено навантаження ендопротезу в сагітальній площині та визначено межу пропорційності, а також жорсткість зразка.

3. Результати експерименту відтворено під час математичного моделювання в COMSOL Multiphysics.

4. Визначено локалізацію максимальних напружень, що виникають в ендопротезі при даному навантаженні.

\section{ПЕРЕЛІК ПОСИЛАНЬ}

[1] Чепишко С. I. Актуальність проблеми оперативних втручань в щелепно-лицевій хірургії та преспективи іiі виришення / С. І. Чепишко, О. О. Максимів. // Клінічна хірургія. -2017 . - №9. - С. 75 - 77

[2] Вивчення впливу анізотропії і неоднорідності кісткової тканини на розподіл напружень у нижній щелепі методом скінченних елементів / М. Г.Крищук, В. О. Маланчук, А. В. Копчак, В. О. Єщенко. // Наукові вісті НТУУ "КПІ". - 2012. №6. - С. 71-76.

[3] Вивчення напружено-деформованого стану скроневонижньощелепного суглоба із використанням імітаційного комп'ютерного моделювання / В. О.Маланчук, В. Г. Крищук, 
О. С. Воловар, Р. С. Паливода. // Інновації в стоматології. 2014. - №4. - С. 65-71.

[4] Напряженно деформированного состояния нижній челюсти при проведении остеосинтеза и реконструктивновосстановительных операций / В. А. Маланчук, А. В. Копчак, Н. Г. Крищук. // Российский стоматологический журнал. 2013. - №2. - С. 8-12.

[5] Шидловський M. C. Експериментальні засоби остеосинтезу / М. С. Шидловський, А. М. Лакши. - Київ: Ленвіт, 2017. - 277 с

[6] Маланчук В. О. Імітаційне моелювання в щелепнолицевій хрургії. Навчальний посібник /Маланчук В.О., Крищук М.Г., Копчак А.В. - К.: Видавничий дім «Асканія», 2013. $-231 \mathrm{c}$
[7] Визначення величини та особливостей розподілу сили прикусу при різних варіантах оклюзії 3 використанням вимірювальних плівок «Fujiprescale» та системи «Tekscan» [В. О. Маланчук, А. В. Копчак, М. Г. Крищук та ін.]. // Український стоматологічний альманах. - 2011. - №6. - С. 43-49.

[8] Маланчук В. О. Зміна механічних властивостей кісткової тканини уламків нижньої щелепи при травматичному переломі / В. О. Маланчук, А. В. Копчак, М. С. Шидловський. // Український стоматологічний альманах. 2009. - №6. - C. 44-48.

[8] COMSOL [Електронний ресурс] : [Веб-сайт]. Електронні дані. - COMSOL, 2019. - Режим доступу: https://www.comsol.eu (дата звернення 30.04.2019) Multiphysics simulation just got better, faster, more accessible.

\title{
УДК 616 - 77
}

\section{МОДЕЛИРОВАНИЕ МЕХАНИЧЕСКОГО НАПРЯЖЕНИЯ НА ЭНДОПРОТЕЗ НИЖНЕЙ ЧЕЛЮСТИ}

\author{
Стасюк Ю.П., аспирант ФБМИ \\ stasuyk.yuriy@gmail.com \\ Черногорский Д. М., аспирант \\ кафедра стоматологи Института последипломного образования \\ НМУ имени А.А. Богомольца \\ cher103@meta.ua \\ Резникова М.Ю., студент \\ reznikovamaryna@gmail.com \\ Факультет биомедицинской инженерии \\ Национальный технический университет Украины \\ «Киевский политехнический институт имени Игоря Сикорского» \\ г. Киев, Украина
}

Реферат- Проблема оптимизации способов эндопротезирования дефектов нижней челюсти на сегодня остается на пике актуальности. Изучение биомеханики имплантов дает возможность определения внутренних напряжений и деформаций, позволяет понять механизм нарушения, а также выбрать оптимальные методы лечения, определить функциональный прогноз хирургических вмешательств.

В статье приведены результаты натурного эксперимента, во время которого проводилось испытание на изгиб в сагиттальной плоскости титанового эндопротеза нижней челюсти. Получено диаграмму деформирования образиаи рассчитана его жесткость. Для определения места локализации максимальных напряжений в эндопротезе, выполнено математическое моделирование деформации образиа, в условиях, которые повторяют проведенный эксперимент. Получено результаты расчета, которые отображают места с максимальным напряжением, что возникает в эндопротезе вследствие действия на него нагрузки.

Ключевые слова - биомеханика, эндопротез, деформачия, нижняя челюсть, метод конечных элементов, механические нагрузки, натурный эксперимент, математическое моделирование, COMSOL Multiphysics 5.4 
UDC $616-77$

\title{
MODELING THE MECHANICAL LOAD OF THE MANDIBLE ENDOPROSTHESIS
}

Stasyuk $Y$., postgraduate student stasuyk.yuriy@gmail.com

National Technical University " Igor Sikorsky Kyiv Polytechnic Institute "

Chernogorskiy D., postgraduate student of Department of Dentist Institute postgraduate education

NMU after A.A. Bogomoltsa cher103@meta.ua

Reznikova M., student reznikovamaryna@gmail.com Faculty of Biomedical Engineering National Technical University " Igor Sikorsky Kyiv Polytechnic Institute " Kyiv, Ukraine

\begin{abstract}
The problem of optimizing the methods of endoprosthesis replacement of tender jaw today remains at the peak of relevance. Studying the biomechanics of implants makes it possible to determine the internal stresses and deformations, allows you to understand the mechanism of the disorder, as well as to choose the optimal treatment methods, to determine the functional prognosis of surgical interventions.

The article presents the results of a full-scale experiment during which a test was carried out on the sagittal plane of the titanium endoprosthesis of the tender jaw. Got a deformation diagram of the blanks and calculated its rigidity. To determine the location of the maximum stress in the endoprosthesis, a mathematical simulation of the deformation of the blanks was performed, under conditions that repeat the experiment. Received the results of the calculation, which reflect the place with the maximum voltage that occurs in the endoprosthesis due to the action on it of the load.
\end{abstract}

Keywords - biomechanics, endoprostheses, deformation, mandible, finite element method, mechanical loads, field experiment, mathematical modeling, COMSOL Multiphysics 5.4. 